\title{
KECERDASAN VISUAL DALAM PEMBELAJARAN DARING BAGI ANAK AKIBAT PANDEMI COVID 19
}

\author{
Dodi Ahmad Haerudin \\ Pendidikan Guru Pendidikan Anak Usia Dini STKIP Muhammadiyah Kuningan \\ Email: dodi@upmk.ac.id \\ Haerudin, Dodi Ahmad. (2021). Kecerdasan Visual dalam Pembelajaran Daring Bagi Anak Akibat Pandemi Covid- \\ 19. Jurnal Pelita PAUD, 5(2), 268-273. \\ doi: https://doi.org/10.33222/pelitapaud.v5i2.1266
}

Abstrak: Penelitian ini bertujuan untuk mengetahui pengembangan kecerdasan visual dalam pembelajaran daring bagi anak terdampak social distancing akibat covid-19. Jenis penelitian yang digunakan yaitu pendekatan deskriptif kaulitatif dengan metode jenis studi kasus. Setting penelitian dilaksanakan di PAUD An Nur di Desa Bakom Kecamatan Darma Kabupaten Kuningan. Subjek dalam penelitian ini yaitu 1 Guru dan 1 wali murid. Data dikumpulkan melalui observasi, wawancara (via whatsApp), dan dokumentasi. Keabsahan data diperiksa dengan triangulasi. Data dianalisis secara deskriptif kualitatif model Miles dan Huberman. Hasil penelitian menunjukkan bahwa kecerdasan visual anak bertambah dari sisi imajinasi anak. Anak dapat menggambarkan ide-ide menarik seperti berimajinasi menggambar covid-19. Dimana sebelumnya anak belum mengetahui secara detail tentang covid-19 serta bahaya dari virus tersebut.

Kata kunci: Kecerdasan Visual, Pembelajaran Daring, Covid-19

Abstract: This study aims to determine the development of visual intelligence in online learning for children affected by social distancing due to COVID-19. The type of research used is a qualitative descriptive approach with a case study type method. The setting of the research was carried out at PAUD An Nur in Bakom Village, Darma District, Kuningan Regency. The subjects in this study were 1 teacher and 1 student guardian. Data were collected through observation, interviews (via WhatsApp), and documentation. The validity of the data was checked by triangulation. The data were analyzed descriptively and qualitatively by the Miles and Huberman model. The results showed that children's visual intelligence increased in terms of children's imagination. Children can describe interesting ideas such as imagining drawing covid-19. Previously, children did not know in detail about COVID-19 and the dangers of the virus.

Keywords: Visual Intelligence, Online Learning, Covid-19 


\section{PENDAHULUAN}

Munculnya virus baru yang diberi nama Corona virus disease-2019 menyebar secara mudah dan cepat di setiap harinya. Penyebaran covid-19 sekarang telah menjadi pandemi di berbagai negara. Hal ini menjadi suatu masalah bagi keberlangsungan hidup masyarakat di seluruh dunia. Akibatnya terjadi peningkatan jumlah pasien, baik pasien positif terkena covid-19 dan korban meninggal dunia.

Indonesia pun tak luput dari ancaman pandemi ini. Dampaknya sangat terasa di berbagai bidang. Misalnya di bidang perekonomian, pendidikan, kesehatan, pertanian, perdangangan, pariwisata dan lainnya. Akibat adanya Covid-19 sangat berpengaruh di bidang pendidikan. Hal tersebut mengakibatkan dapat menghambat proses belajar mengajar. Kegiatan pembelajaran yang semula dilakukan secara tatap muka di sekolah sekarang diganti dengan pembelajaran daring. Diberlakukan pembelajaran daring sesuai dengan Surat Edaran Mendikbud Nomor 4 Tahun 2020 perihal pelaksanaan belajar dari rumah melalui pembelajaran daring yang difokuskan pada pendidikan mengenai kecakapan hidup yang harus dilakukan dalam menganangani pandemi covid-19. Dengan pembelajaran daring diharapkan mampu mengurangi interaksi secara langsung di lingkungan sekolah. Hal ini bertujuan untuk menekan laju penyebaran covid-1d.

Berdasarkan Peraturan Menteri Kesehatan Republik Indonesia Nomor 9 Tahun 2020 pada pasal 1 ayat 2 yang berisi tentang Pembatasan Sosial Berskala Besar. Menyatakan bahwa pembatasan kegiatan tertentu pada penduduk dalam suatu wilayah yang diduga terinfeksi Corona Virus Disease 2019 (COVID-19) digunakan sebagai upaya untuk mencegah kemungkinan penyebaran Corona Virus Disease 2019 / Covid-19 (Dalinama Telaumbanua, 2020). Adanya isolasi dalam jaringan sosial dapat meminimalisasi adanya peluang dalam bertambahnya kasus penyebaran virus corona disease 2019 (Nailul Mona, 2020).

Dalam proses pembelajaran di PAUD An Nur akibat adanya pandemi covid-19 menggunakan sistem pembelajaran daring via aplikasi whatsApp. Pembelajaran yang dilakukan di rumah menggunakan bantuan smartphone. Menurut Daffy, dkk (dalam Muhammad Yaumi, 2018: 30) menyatakan bahwa dalam sebuah pembelajaran dapat menggunakan teknologi yang dapat digunakan oleh pendidik dalam menyampaikan pembelajaran. Hal ini digunakan untuk mendukung proses belajar mengajar agar dapat berjalan secara efektif. Penggunaan smartphone dinilai sangat efektif dalam melakukan pembelajaran daring di PAUD An Nur. Setiap hari guru mengirimkan pembelajaran berupa video yang berisi tentang kegiatan yang harus dilakukan anak dirumah. Dengan tetap mempertahankan proses belajar walaupun pembelajaran dilakukan dengan sistem daring diharapkan dapat mengembangkan semua aspek perkembangan pada diri anak termasuk perkembangan visual spasial anak.

Kecerdasan pada diri anak menurut Gardner (dalam Anita Yus,1999: 10) terbagi menjadi 8 kecerdasan, yaitu kecerdasan bahasa, kecerdasan logika-matematika, kecerdasan musik, kecerdasan kinestetik, kecerdasan visual, kecerdasan intrapersonal, kecerdasan interpersonal, kecerdasan naturalis dan kecerdasan spriritual. Dalam mengembangkan berbagai aspek perkembangan dalam diri anak, hal ini terkait dengan potensi pada diri manusia yang bertumpu pada otak (Suyadi, 2012). Otak merupakan suatu kompenen yang sangat penting dan fungsional yang menjadi dasar manusia dalam proses belajar (Taufiq Pasiak, 2006: 47). Perkembangan pada anak usia dini disebut perkembangan golden age, karena pada masa perkembangan ini pertumbuhan sel otak anak yaitu mencapai $50 \%$ pada usia $0-4$ tahun dan mencapai $80 \%$ hingga usia 8 tahun. Perkembangan otak bersamaan dengan perkembangan pada fisik anak (Aas Siti Sholichah, 2020).

Proses pembelajaran daring tidak terlepas dari peran para orangtua anak. Orangtua menjadi jembatan dalam proses pembelajaran yang dilakukan secara daring (Cahyati \& Kusumah, 2020). Lingkungan belajar dirumah menjadi faktor penting dalam hal tersebut, terutama pola asuh yang diberikan orangtua kepada anaknya (Junierissa Marpaung, 2017). Misalnya cara orangtua dalam menyampaikan materi yang diberikan oleh guru, cara orangtua membimbing anak dalam mengerjakan tugas-tugas sesuai instruksi guru, dan lain sebagainya. Kerjasama yang terjalin antara guru dan orangtua menjadi kunci utama dalam berlangsungnya kegiatan pembelajaran daring untuk mengembangkan segala aspek perkembangan pada diri anak. 
Dalam meningkatkan kecerdasan visual anak dapat dilakukan melalui berbagai kegiatan, salah satunya dengan kegiatan menggambar. Dalam pengembangan visual spasial guru dapat menggunakan berbagai media dan kegiatankegiatan yang kreatif bagi anak. Kecerdasan visual berkaitan dengan keterampilan dalam bermain garis, warna, bentuk dan ruang. Dalam mengembangkan kecerdasan visual dengan cara memberikan kegiatan pada anak didik seperti kegiatan menggambar dan mewarnai sebuah poster, membuat prakarya masker dan lain-lain. Menggambar merupakan kegiatan yang dilakukan dengan cara mencoret-coret, menggores, menorehkan benda-benda tajam ataupun benda dalam bentuk lainnya serta memberikan warna agar menimbulkan suatu gambar (Hajar Pamadhi, Evan Sukardi,2008: 2.5). Anak dapat menggambar bebas dengan mengekpresikan sesuatu melalui gambar dan mewarnai sesuai dengan keinginannya (Reni Sri Wahyuni, 2018). Dalam menggambar mampu menciptakan daya imajinatif anak, hal ini sejalan dengan pendapat Primadi (dalam Sumanto,2016) menyatakan bahwa kemampuan kreatifitas yang dimunculkan oleh anak merupakan suatu kesatuan dari kemampuan fisik, rasio, imajinasi anak, perasaan dan geraknya.

Anak usia dini cenderung lebih banyak memasukkan imajinasi dalam dunia mereka. Imajinatif kreatif pada diri anak merupakan teknik dalam mengoptimalkan fungsi otak secara lebih maksimal dengan melakukan berbagai kegiatan yang dapat menstimulus imajinasi kreatif pada diri anak (Desfa Yumaliyana, Suyadi, 2019). Banyaknya penemuan-penemuan terjadi karena imajinasi dan simulasi dalam otak anak. Mental imaging sangat berkaitan erat dengan imajinasi seorang anak. Semakin sering anak melakukan mental imaging maka semakin banyak anak akan menemukan berbagai cara untuk menyelesaikan masalah-masalah yang sedang ia dihadapi (Taufik Pasiak, 2006: 57). Penelitian ini penting dilakukan untuk mengembangkan kecerdasan visual dalam pembelajaran daring bagi anak terdampak social distancing akibat covid-19 di PAUD An Nur. Penelitian ini dapat menjadi evaluasi dalam pendidikan terkait adanya pembelajaran daring akibat covid-19.

\section{METODE PENELITIAN Jenis Penelitian}

Penelitian yang digunakan dalam penelitian ini adalah penelitian kualitatif dengan metode penelitian fenomenologi. Menurut Erickson (dalam Albi Anggito, Johan Setiawan, 2018: 7) menyatakan bahwa penelitian kualitatif bertujuan untuk menemukan dan menggambarkan secara naratif, mendiskripsikan kegiatan-kegiatan yang dilakukan akibat dari kegiatan tersebut yang berdampak pada kehidupan mereka. Dalam penelitian ini menggambarkan objek secara apa adanya. Menurut Bogdan dan Biklen (dalam A Muri Yusuf, 2014: 351) menyatakan bahwa pada penelitian fenomenologi bertujuan untuk menggali, memahami, dan menafsirkan suatu fenomena yang hendak diteliti dalam suatu situasi dan kondisi tertentu. Hal ini sesuai dengan tujuan penelitian untuk mengetahui bagaimana pengembangan kecerdasan visual anak dalam pembelajaran daring bagi anak terdampak social distancing akibat adanya pandemi covid-19 saat ini. Menggali informasi secara detail bagaimana upaya yang dilakukan oleh guru agar perkembangan visual anak selama adanya pandemi covid-19 ini tetap berjalan seperti saat pembelajaran tatap muka di sekolah.

\section{Waktu dan Tempat Penelitian}

Penelitian ini dilakukan pada semester II tahun pelajaran 2019/2020 tepatnya pada bulan April dengan setting penelitian di PAUD An Nur yang beralamat di desa Bakom Kecamatan Darma Kabupaten Kuningan.

\section{Subjek Penelitian}

Subjek dalam penelitian ini terdiri dari 1 orang guru dan 1 wali murid di PAUD An Nur Kabupaten Kuningan

\section{Prosedur}

Prosedur dalam penelitian ini diawali dengan pengumpulan data melalui instrument dalam dengan menggunakan pedoman wawancara berisi kisi-kisi pertanyaan yang ditujukan guru dan wali murid yang menjadi sampel, sebagai komponen relevansi yang diamati, deskripsi, serta verifikasi atau penarikan kesimpulan dari observasi tersebut. Telaah dokumen mengacu pada telaah dokumen atau arsip-arsip sekolah yang berhubungan dengan penerapan pembelajaran yang diajarkan oleh guru dalam program pembelajaran selama pandemic covid-19.

Data, Instrumen, dan Teknik Pengumpulan Data

Teknik pengumpulan data yang digunakan dalam penelitian dilaksanakan dengan teknik 
wawancara, observasi, dan telaah dokumen. Wawancara terhadap guru dan wali murid (via aplikasi whatsApp). Berdasarkan kisi-kisi observasi yang telah dirancang. Telaah dokumen dilaksanakan dengan cara mengumpulkan data yang bersumber dari dokumen atau arsip yang terkait.

\section{Teknik Analisis Data}

Dalam penelitian ini menggunakan teknis pengumpulan data dengan menggunakan model Miles dan Hubermen. Menurut Miles dan Hubermen (dalam Amuri Yusuf, 2019: 407) mengemukakan bahwa penelitian kualitatif terkumpul melalui berbagai teknik pengumpulan data yang berbeda-beda misalnya interview, observasi, kutipan, sari dari dokumen, catatan dengan tape. Aktivitas analisis data meliputi reduksi data, penyajian data dan penarikan kesimpulan. Data yang telah dikumpulkan melalui wawancara kemudian disusun menjadi data yang relevan sehingga menjadi informasi yang berarti dalam bentuk uraian naratif. Data tersebut dapat memberi kemudahan bagi peneliti dalam menarik kesimpulan.

\section{HASIL PENELITIAN DAN PEMBAHASAN}

Imajinasi merupakan bagian integral perkembangan setiap anak, dengan mengajarkan dan memberi kesempatan dalam belajar. Berimajinasi perlu disediakan dalam menciptakan lingkungan belajar yang baik untuk anak. Kemampuan memahami suatu objek yang abstrak maupun kompleks, seperti halnya dengan konsep kecerdasan visual anak berdasarkan dimensinya, akan memberikan keterampilan dalam stimulus yang imajinatif bagi anak. Pembelajaran yang dirancang secara baik dan kreatif dengan memanfaatkan multimedia, dalam batas-batas tertentu akan dapat memperbesar kemungkinan siswa untuk belajar lebih banyak mencamkan apa yang dipelajarinya, lebih baik, dan meningkatkan penampilan (performance) siswa dalam rangka meningkatkan ketercapaian kompetensi (Miftah, 2013).

Masa ini menjadikan sistem daring menjadi hal yang tidak lagi aneh karena semua sekolah menggunakannya. Semua guru dan orang tua siswa mengalami penguasaan baru yaitu teknologi yang digunakan untuk belajar jarak jauh. Proses belajar dirumah menggunakan teknologi menjadi keahlian yang harus dimiliki oleh semua guru di setiap sekolah karena menunjang kelancaran dan proses belajar yang berkelanjutan.

Kecerdasan dalam paradigma multiple inttelegence menurut Gardner (dalam Musfiroh 2009: 1-5) diidentifikasikan sebagai kemampuan yang mempunyai tiga komponen utama, yakni: (1) kemampuan untuk menyelesaikan masalah yang terjadi dalam kehidupan sehari-hari, (2) kemampuan untuk menghasilkan persoalanpersoalan baru yang dihadapi untuk diselesaikan, dan (3) kemampuan untuk menciptakan sesuatu atau menawarkan jasa yang akan menimbulkan penghargaan dalam budaya seseorang.

Penelitian yang dilakukan terhadap 1 guru dan 1 wali murid PAUD An Nur dengan hasil penelitian bahwa selama proses pembelajaran daring akibat covid-19, pengembangan kecerdasan visual berjalan dengan baik. Anak mampu memahami perintah dan mengikuti instruksi guru yang disebarkan melalui video di grup WhatsApp kelas. Hasil yang telah dikerjakan anak kemudian didokumentasikan dan dikirim ke grup WhatsApp kelas dengan peraturan maksimal pengiriman pukul 21.00 WITA, sehingga guru dapat memberikan penilaian secara langsung pada hari itu juga. Peran orangtua dalam kegiatan pembelajaran daring saat ini sangat berpengaruh dalam pengembangan kecerdasan anak. Orangtua harus mampu memberikan bimbingan kepada anak dalam menyampaikan materi yang telah diberikan oleh guru. Sehingga dalam pengembangan kecerdasan anak dapat berkembang dengan maksimal walaupun dalam pembelajaran daring akibat adanya covid-19 ini.

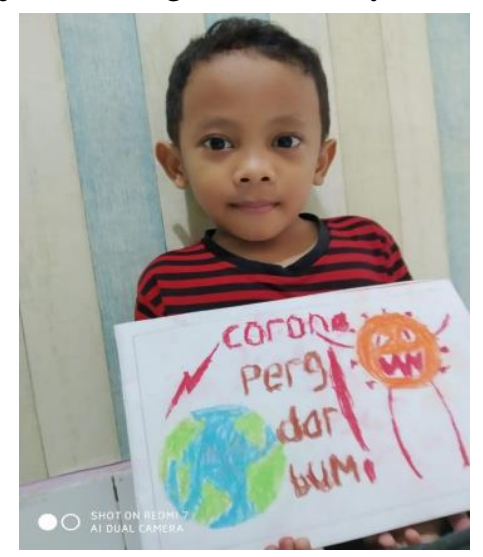

Gambar 1. Kegiatan menggambar bebas 
Pada Gambar 3.1 kegiatan menggambar bebas tentang covid-19. Anak berkreasi dengan pengalaman baru yang ia dapatkan tentang apakah itu covid-19. Dalam gambar tersebut terlihat bahwa dalam memahami tentang adanya virus corona, selain menggambarkan virus yang memiliki karakter yang jahat, anak juga berimajinasi bahwa virus tersebut memiliki tangan, kaki, mata, mulut dan gigi. Yang menggambarkan bahwa virus tersebut seperti monster berukuran kecil dan jahat. Kemudian ada juga gambar bumi yang bulat anak menuangkan idenya dengan memberi warna biru dan hijau yang berarti bahwa bumi kita adalah terdiri dari lautan dan daratan. Selain gambar anak juga menyisipkan kata-kata yaitu "Corona pergi dari bum!”.

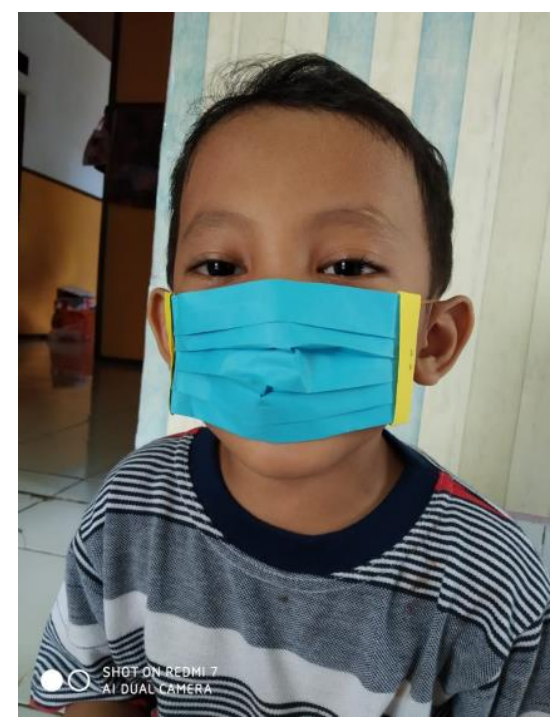

Gambar 2 Kegiatan membuat masker

Pada Gambar 3.2 adalah hasil dari kegiatan anak dalam kegiatan membuat masker. Dalam kegiatan ini anak membuat masker menggunakan bahan utama yaitu dari kertas lipat/ kertas origami. Alat dan bahan ang dibutuhkan dalam membuat masker ini adalah, kertas oigami warna biru muda, kertas origami warna kuning, 2 buah karet gelang, lem serta steples. Dalam kegiatan membuat masker ini, sebelumnya anak diberikan instruksi dari guru berupa video yang dibuat oleh guru melalui WhatsApp Grup. Guru membuat seuah video dengan memperagakan bagaimana langkah-langkah dalam membuat masker kertas. Kemudian anak menirukan langkah-langkah dari guru untuk membuat prakarya tersebut. Dalam hal ini kecerdasan visual anak dikembangkan dengan cara anak menonton dan menyimak langkah-langkah dalam membuat sebuah prakarya. Anak mengamati secara langsung bagaimana proses pembuatannya. Anak memiliki gambaran tentang apa yang harus anak lakukan dalam membuat masker kertas.

\section{SIMPULAN}

Berdasarkan hasil penelitian dapat disimpulkan bahwa kegiatan pembelajaran melalui pembelajaran daring dengan cara guru mengirimkan video pembelajaran anak via WhatsApp dapat berjalan dengan baik. Pembelajaran yang dilakukan di rumah dengan berbagai kegiatan dapat mengembangkan kecerdasan anak. Kegiatan menggambar dan mewarnai poster yang berkaitan tentang covid-19 ini dapat meningkatkan daya imajinasi anak dalam pengembangan kecerdasan visual spasial anak.

\section{DAFTAR PUSTAKA}

Anggito, Albi \& Setiawan Johan. (2018). Metodologi Penelitian Kualitatif. Sukabumi: CV Jejak.

Cahyati, N., \& Kusumah, R. (2020). Peran Orang Tua Dalam Menerapkan Pembelajaran Di Rumah Saat Pandemi Covid 19. Jurnal Golden Age, Universitas Hamzanwadi, 04(1), 4-6.

Kementrian Kesehatan RI. (2020). Pedoman Pembatasan Sosial Berskala Besar Dalam Rangka Percepatan Penanganan Corona Virus Diesase 2019 (Covid-19). Diakses tanggal 20 April 2020 dari https://www.kemkes.go.id/article/view/20031 700001/Dokumen-Resmi-dan-ProtokolPenanganan-COVID-19.html.

Marpaung, Junierissa. (2017). Pengaruh Pola Asuh Terhadap Kecerdasan Majemuk Anak. Jurnal Kopasta. 4(1).

Miftah, M. 2013. Sebagai Upaya Peningkatan Kemampuan Belajar Siswa. Jurnal Kwangsan. Vol 1(2)

Mona, Nailul. (2020). Konsep Isolasi Dalam Jaringan Sosial Untuk Meminimalisasi Efek Contagious (Kasus Penyebaran Virus Corona Di Indonesia). Jurnal Sosial Humaniora Terapan. 2(2). 117-1.

Musfiroh, Takdiroatun. 2009. Menumbuh Kembangkan Baca Anak Usia Dini. Jakarta: Grasindo

Pamadhi, Hajar \& Sukardi, S Evan. (2008). Seni Keterampilan Anak. Jakarta: Universitas Terbuka.

Pasiak, Taufiq. (2006). Manajemen Kecerdasan. Bandung: Mizan Pustaka.

Reni Sri Wahyuni. (2018). Upaya Meningkatkan Kecerdasan Visual Spasial Melalui Kegiatan Menggambar Pada Anak Usia Dini KeLompok A. Jurnal Tunas Siliwangi, 1(4), 38. 
Sholichah, Aas Siti. (2020). Urgensi Pendidikan Karakter Pada Anak Usia Dini Dalam Tinjauan Neurosains. Jurnal of Early Childhood Islamic Education Study. 01(01)

Sumanto. (2016). Makna Simbolis Gambar AnakAnak. Jakarta: Gunung Samudra.

Telaumbanua, Dalinama. (2020). Urgensi Pembentukan Aturan Terkait Pencegahan Covid-19 di Indonesia. Jurnal Pendidikan, Sosial, dan Agama. 12(1).

Yaumi, Muhammad. (2018). Media Dan Teknologi Pembelajaran. Jakarta: Prenada Group.

Yus, Anita. (2011). Model Pendidikan PAUD. (1 $\left.{ }^{\text {st }} e d\right)$. Jakarta: Prenada Group.

Yusmaliana, Desfa \& Suyadi. (2019). Pengembangan Imajinasi Kreatif Berbasis Neurosains Dalam Pembelajaran Keagamaan Islam. Jurnal Penelitian Pendidikan Islam. 14(2). 267-268.

Yusuf, A Muri. (2014). Metode Penelitian Kuantitatif, Kualitatif \& Gabungan. Jakarta: Prenada Group. 